\title{
ANALISIS KEMAMPUAN GURU DALAM MENUMBUHKAN KEDISIPLINAN SISWA KELAS III SEKOLAH DASAR \\ Oleh
}

Tri Yudha Setiawan

SDN 187/VIII Bangun Seranten

Yudhasetiawan252@gmail.com

Diterima 7 Maret 2021, direvisi 24 Maret 2021, diterbitkan 1 April 2021

\begin{abstract}
Abstrak
Penelitian ini memiliki tujuan untuk mendeskripsikan kemampuan guru dalam menumbuhkan sikap disiplin siswa kelas III sekolah dasar. Jenis pendekatan yang digunakan dalam penelitian ini adalah kualitatif, yang menghasilkan data berupa deskriptif. Data dalam penelitian ini menggunakan 2 data yaitu data primer dan data sekunder. Teknik pengumpulan data yaitu mengunakan teknik observasi, wawancara serta dokumentasi. Informan dalam penelitian ini adalah guru kelas III. Hasil observasi menunjukan beberapa upaya yang dilakukan oleh guru kelas III dalam menumbuhkan sikap disiplin yaitu pembuatan peraturan kelas, pembuatan jadwal piket kelas dan pemberian nilai tambah bagi siswa yang memiliki sikap disiplin. Selain itu guru juga memberikan reward beserta motivasi yang bertujuan untuk meningkatkan kedisiplinan siswa kelas III. Upaya yang dilakukan oleh guru membuat siswa memiliki sikap disiplin. Sikap disiplin tercapai berdasarkan indikator (1) mentaati peraturan yang ada disekolah, (2) hadir dikelas tepat waktu, (3) memakai pakaian sesuai dengan ketentuan, (4) mengumpulkan tugas dan pekerjaan rumah tepat waktu, (5) melaksanakan piket kebersihan kelas sesuai dengan jadwal yang ditetapkan.
\end{abstract}

\section{Kata Kunci: Disiplin, Pendidikan Karakter, sekolah dasar}

\begin{abstract}
This study aims to describe the ability of teachers to foster the attitudes of third grade elementary school students. The type of approach used in this research is qualitative, which produces descriptive data. The data in this study used 2 data, namely primary data and secondary data. The data technique used was observation, interview and documentation techniques. The informants in this study were class III teachers. The results of the observations show the efforts made by class III teachers in fostering a disciplined attitude in how to make class rules, making class schedules and giving added value to students who have a disciplined attitude. In addition, the teacher also provides rewards along with motivation which aims to improve discipline in grade III students. The efforts made by the teacher make students have a disciplined attitude. Discipline depends on indicators (1) obeying the existing rules at school, (2) attending class on time, (3) wearing clothes in accordance with the provisions, (4) determining assignments and homework on time, (5) carrying out class cleaning pickets accordingly with a set schedule.
\end{abstract}

\section{Keywords: Discipline, Character Education, elementary schoolPENDAHULUAN}

Pendidikan karakter perlu dilakukan untuk menanamkan sikap yang baik untuk siswa, pendidikan dilakukan sedini mungkin mulai dari lingkungan keluarga, lingkungan sekolah serta lingkungan masyarakat. Di lingkungan sekolah siswa akan mendapatkan pendidikan karakter yang diberikan oleh guru, karena sekolah merupakan salah satu pendidikan formal 
yang mengemban tugas untuk menumbuhkan karakkter siswa. Salah satu karakter yang perlu ditumbuhkan dan dikembangkan pada siswa sekolah dasar adalah disiplin.

Disiplin merupakan perasaan patuh terhadap sesuatu yang dipercayai melalui tindakan yang selalu konsisten/tetap (Febriyanto et al., 2020). Siswa didalam lingkungkan sekolah atau luar sekolah harus memilikis sikap displin yang baik. Sikap disiplin merupakan suatu tindakan yang menunjukan perilaku patuh dan tertib dengan kententuan dan peraturan yang ada (Kemdikbud, 2016). Sikap disiplin pada siswa dapat dilihat dari perbuatan serta tindakan yang tercermin pada kegiatan sehari-harinya disekolah (Chan et al., 2020). Manfaat disiplin bagi siswa yaitu untuk mengajarkan keteraturan dan kepedulian untuk menjadikan diri lebih baik. Selain itu, Sikap disiplin membantu siswa dalam membangun pengendalian diri mereka sendiri (Salam \& Anggraini, 2018). Guru sebagai tenaga pengajar dan pendidik memiliki peran mentransfer ilmu pengetahuan, menumbuhkan dan mengembangkan karakter siswa melalui interaksi yang terjadi dilingkungan sekolah (Sanders et al., 2017). Dalam pendidikan karakter, peran guru sangat dibutuhkan sebagi sosok yang menjadi idola karena sumber inspirasi dan motivasi bagi siswa (Alfath, 2020).

Peran yang dilakukan oleh guru dalam menumbuhkan dan mengembangkan karakter siswa membuat peneliti tertarik untuk meneliti, oleh sebab itu peneliti melakukan observasi awal untuk langkah pertama dalam penelitian. Peneliti memilih kelas III. Siswa kelas III memiliki kecenderungan rasa ingin tahu yang cukup tinggi serta gemar dalam membentuk kelompok-kelompok kecil dalam lingkungan sekolah.

Berdasarkan observasi awal peneliti menemukan bahwa siswa kelas III sebagian besar telah memiliki sikap disiplin yang berkategori baik. Hal tersebut dilihat dari siwa yang dating tepat waktu dan siswa yang selalu menjaga kebersihan baik dilingkungan sekolah dan lingkungan kelas.

Berdasarkan hasil observasi yang telah diuraikan, maka peneliti ingin melihat lebih dalam cara yang dilakukan oleh guru untuk menumbuhkan kedisiplinan siswa kelas III sekolah dasar.

\section{METODE}

Pada penelitian ini jenis penelitian yang digunakan adalah kualitatif dengan hasil berupa data deskriptif yaitu kata-kata yang didapatkan dari subjek penelitian. Penelitian dilakukan di kelas III sekolah dasar. Waktu penelitian dilakukan pada semester genap.

Sumber data dalam penelitian ini ada 2 yaitu data primer dan data sekunder. Data primer didapatkan dari subjek utama penelitian sedangan data sekunder yang berperan sebagai data pendukung didapatkan melalui pendokumentasian kegiatan. Data yang diambil dalam penelitian ini yaitu kemampuan guru dalam menumbuhkan kedisiplinan siswa.

Pada penelitian ini menggunakan teknik pengumpulan data yaitu dengan menggunakan observasi, wawancara serta pendokumentasian. Dalam penelitian ini teknik yang utama digunakan adalah observasi.

Observasi digunakan oleh peneliti karena aspek yang akan diteliti sangat cocok menggunakan teknik observasi atau pengamatan secara langsung yang dilakukan oleh peneliti sendiri.

Informan dalam penelitian ini adalah guru kelas. Pemilihan informan didasarkan oleh anggapan peneliti. Pemilihan tersebut berguna untuk memperoleh data secara akurat dan tepat. Informan adalah orang yang mengetahui secara mendalam apa yang hendak diketahui oleh penanya berdasarkan pengalaman serta informasi yang dialami secara langsung. 
Peneliti mengunakan triangulasi teknik dalam menguji keabsahan data. Dalam mengelolah data peneliti melakukan beberapa tahapan yaitu mengumpulkan data, meyajika data berupa data deskriptif dan yang terakhir penyajian data berupa karya ilmi

\section{PEMBAHASAN}

Guru memiliki peran penting dalam menumbuhkan sikap disiplin siswa, kerena seorang siswa yang disiplin disebabkan oleh pembiasaan yang dilakukan sehari-hari. Siswa bersikap disiplin jika telah mencapai indikator disiplin. Indikator disiplin merujuk pada paduan penilaian tahun 2016. Berikut adalah indikator disiplin yang telah dibuat oleh peneliti.

\section{Tabel 1. Indikator disiplin}

\begin{tabular}{|c|l|}
\hline Pendidikan Karakter & \multicolumn{1}{|c|}{ Indikator } \\
\hline Disiplin & - Mentaati peraturan yang ada disekolah \\
& - Hadir di kelas tepat waktu \\
& - Memakai pakaian sesuai dengan ketentuan \\
& - Mengumpulkan tugas dan pekerjaan rumah tepat waktu \\
& - Melaksanakan piket kebersihan kelas sesuai dengan jadwal \\
& yang ditetapkan \\
\hline
\end{tabular}

Sikap disiplin tumbuh karena guru memberikan peran dalam menumbuhkan sikap disiplin tersebut. Nilai kedisiplinan diperoleh melalui kegiatan sehari-hari, kegiatan rutin, keteladanan dan pengkondisian. Sikap disiplin sangat penting karena merupakan titik masuk untuk memulai pendidikan karakter karena jika tidak ada sikap disiplin diantaranya rasa hormat, otoritas, hak, maka tidak aka nada rasa nyaman dan lingkungan yang baik dalam proses belajar mengajar (Suryanti \& Arafat, 2018). Hal- hal yang dilakukan oleh guru kelas III sebagi berikut:

\section{Membuat Peraturan Kelas}

Hasil observasi yang dilakukan oleh peniliti, maka peneliti mendapatkan bahwa guru membuat praturan kelas seperti siswa hadir tepat waktu dikelas, mengerjakan tugas dengan baik, tidak membuang sampah sembarangan serta berbapakain seragam sesuai yang telah ditentukan. Pembuatan aturan kelas akan memberikan kejelasan batasan-batasan perilaku siswa dikelas (Annisa, 2019). Selain peraturan kelas guru juga menerapkan peringatan dan sanksi apabila siswa melanggar. Sanksi tersebut dibuat untuk membangun kedisiplinan siswa. Sanksi yang diterapkan juga mengandung nilai yang bermakna seperti sanksi megambil sampah ataupun yang lainnya. Pemberian hukuman atau sanksi akan memberikan efek jera kepada siswa jika mereka melanggar aturan (Ansori, 2020)

\section{Membuat Jadwal Piket Kelas}

Hasil observasi dan wawancara maka diperoleh data bahwa guru diawal semester membuat jadwal piket untuk siswa. Siswa diberikan tanggung jawab untuk membersihkan kelas. Dalam pembuatan jadwal piket guru mengelompokkan siswa dan mengatur jadwal berdasarkan hari.

Pembuatan jadwal piket kelas disepakati bersama. Guru juga memiliki peran dalam mengontrol siswa dalam melaksanakan piket dan ikut dalam menjaga kebersihan kelas. Dalam kegiatan piket kelas terdapat pembentukan sikap disiplin yaitu kepatuhan siswa dalam melaksanakan tugas sesuai dengan jadwal dan kelompok yang telah ditentukan (Afriadi et al., n.d.) 


\section{Memberi Nilai Tambahan dan Reward}

Berdasarkan hasil observasi dan wawancara dapat disimpulkan bahwa guru memberikan nilai tambahan jika siswa memiliki sikap disiplin yang baik seperti mengerjakan tugas tepat waktu dan dating tepat waktu. Selain itu juga guru memberikan reward kepada siswa yang disiplin serta motivasi untuk selalu membiasakan diri bersikap disiplin. Pemberian reward bertujuan untuk memotivasi siswa agar berprilaku yang baik dan menunjukan bahwa tingkah laku siswa tersebut sesuai dengan yang diharapkan lingkungannya (Pratama \& Suwanda, 2013).

Merujuk pada indikator disiplin, maka dapat diketahui bahwa guru melakukan upaya dalam pencapaian indikator-indikator tersebut dengan membuat peraturan kelas, membuat jadwal piket dan memberikan nilai tambahan serta reward bagi siswa. Upaya tersebut membberikan dampak bagi siswa yaitu siswa memiliki sikap disiplin yang baik dibuktikan dengan ketercapaiannya indikator disiplin.

\section{SIMPULAN}

Berdasarkan hasil dan pembahasan yang telah peneliti uraikan maka dapat disimpulkan bahwa sebagian besar siswa kelas III telah memiliki sikap disipin. Sikap disiplin tersebut dilihat dari ketercapaian indikator yang telah dibuat dalam penelitian ini. Ketercapaian siswa yaitu menaati peraturan kelas yang dibuat oleh guru, mengerjakan tugas tepat waktu, menjaga kebersihan lingkungan kelas dan sekolah. Ketercapaian tersebut diakibatkan oleh upaya guru dalam pembentukan sikap disiplin.

Guru telah memiliki kemampuan dalam menumbuhkan kedisiplinan siswa melalui pengadaan aturan-aturan yang dibuat serta memberikan nilai tambahan dan reward bagi siswa yang disiplin. Hal tersebut memberikan dampak berupa pembiasaan sikap disiplin bagi siswa.

\section{DAFTAR PUSTAKA}

Afriadi, B., Islam, U., \& Yusuf, S. (n.d.). Problematika pendisiplinan perilaku normatif dalam kegiatan piket kelas. 527-536.

Alfath, K. (2020). Pendidikan Karakter Disiplin Santri Di Pondok Pesantren Al-Fatah Temboro. Journal Al-Manar, 9(1), 125-164. https://journal.staimsyk.ac.id/index.php/almanar/article/view/136\%0Ahttps://journal.stai msyk.ac.id/index.php/almanar/article/download/136/117

Annisa, F. (2019). Penanaman Nilai-Nilai Pendidikan Karakter Disiplin Pada Siswa Sekolah Dasar. Perspektif Pendidikan Dan Keguruan, 10(1), 69-74. https://doi.org/10.25299/perspektif.2019.vol10(1).3102

Ansori, Y.Z. (2020). Penguatan karakter disiplin siswa melalui peranan guru di sekolah dasar. Jurnal Elementaria Edukasia, 3(1), 126-135.

Chan, F., Kurniawan, A. R., Melinda, L. G., Priantini, R., Zubaedah, Z., Suharti, S. R., \& Khodijah, S. (2020). Implementasi Pendidikan Karakter Disiplin Pada Peserta Didik Di Sd Negeri 187/1 Teratai. PENDAS MAHAKAM: Jurnal Pendidikan Dasar, 4(2), 137-145. https://doi.org/10.24903/pm.v4i2.405

Febriyanto, B., Patimah, D. S., Rahayu, A. P., \& Masitoh, E. I. (2020). Pendidikan Karakter 
Dan Nilai Kedisiplinan Peserta Didik Di Sekolah. Jurnal Elementaria Edukasia, 3(1), 8591.

Kemdikbud.go.id. (2016). Panduan Penilaian. Http://Kemdikbud.Go.Id/, 021 . http://kemdikbud.go.id/main/?lang=id

Pratama, A. H., \& Suwanda, I. M. (2013). Strategi pembentukan disiplin siswa melalui pelaksanaan tata tertib di SMA Negeri 1 Krian Sidoarjo. Jurnal Kajian Moral Dan Kewarganegaraan, 1(1), 85-100. file:///C:/Users/7/Downloads/1466-2890-1-SM.pdf

Salam, M., \& Anggraini, I. (2018). Kedisiplinan Belajar Siswa Kelas V Di SDN 55/I Sridadi. Jurnal Gentala Pendidikan Dasar, 3(1), 127-144. https://doi.org/10.22437/gentala.v3i1.6777

Sanders, M. G., Lukmansyah, D., Danniarti, R., \& Moh. Rois, Fartika Ifriqia, D. S. (2017). Jurnal Manajemen, Kepemimpinan, dan Supervisi Pendidikan Volume 1, No. 1, JuliDesember 2017. American Journal of Education, 1(2), 233-255. The Value of Pancasila, National Insight, PPKn Subject

Suryanti, I., \& Arafat, Y. (2018). Implementasi Pendidikan Karakter Disiplin Dan Tanggung Jawab Di Sd Negeri 18 Air Kumbang. JMKSP (Jurnal Manajemen, Kepemimpinan, Dan Supervisi Pendidikan), 3(2). https://doi.org/10.31851/jmksp.v3i2.1860 